\title{
The Role of Canonical Wnt Signaling in Regulating Radioresistance
}

\author{
Yuanyuan Zhao ${ }^{\mathrm{a}} \quad$ Leilei Tao $^{\mathrm{a}} \quad$ Jun Yi ${ }^{\mathrm{b}}$ Haizhu Song ${ }^{\mathrm{a}}$ Longbang Chen ${ }^{\mathrm{a}}$ \\ aDepartment of Medical Oncology, Jinling Hospital, Medical school of Nanjing University, Nanjing, \\ Jiangsu, ${ }^{b}$ Department of Cardiothoracic Surgery, Jinling Hospital, Medical School of Nanjing University, \\ Nanjing, Jiangsu, China
}

\section{Key Words \\ Wnt/ $\beta$-catenin $\bullet$ Radioresistance $\cdot$ DNA repair $\bullet$ ROS $\bullet$ Apoptosis}

\begin{abstract}
Radioresistance is a major obstacle in radiotherapy for cancer, and strategies are needed to overcome this problem. Currently, radiotherapy combined with targeted therapy such as inhibitors of phosphoinosotide 3-kinase/Akt and epidermal growth factor receptor signaling have become the focus of studies on radiosensitization. Apart from these two signaling pathways, which promote radioresistance, deregulation of Wnt signaling is also associated with the radioresistance of multiple cancers. Wnts, as important messengers in the tumor microenvironment, are involved in cancer progression mainly via canonical Wnt signaling. Their role in promoting DNA damage repair and inhibiting apoptosis facilitates cancer resistance to radiation. Thus, it seems reasonable to target Wnt signaling as a method for overcoming radioresistance. Many small-molecule inhibitors that target the Wnt signaling pathway have been identified and shown to promote radiosensitization. Therefore, a Wnt signaling inhibitor may help to overcome radioresistance in cancer therapy.

\section{Introduction}

Radiotherapy is a powerful and common tool for the treatment of cancer. In fact, it is estimated that about one-half to two-thirds of cancer patients receive this type of therapy [1]. Although it has many advantages including local tumor control, a large proportion of patients experience radioresistance and cancer recurrence [2]. It is therefore necessary to determine the mechanisms underlying radioresistance and identify new pharmacological strategies to improve the efficiency of radiotherapy.

Several mechanisms of radioresistance have been suggested, involving cancer stem cells (CSCs), apoptosis, reactive oxygen species (ROS), and DNA damage repair. Currently, radiotherapy combined with targeted therapy has become the focus of studies on

Y. Zhao and L. Tao contributed equally to this work.

Haizhu Song

and Longbang Chen
Department of Medical Oncology, Jinling Hospital, School of Medicine,

Nanjing University, Nanjing, Jiangsu 210002 (China)

E-Mail songhaizhu@163.com, dr.chenlb@163.com 
radiosensitization [3], so elucidating the signaling pathways involved in radioresistance is of primary importance.

Tumorigenesis involves a series of changes including the activation of oncogenes and inactivation of suppressor genes, and it is now well recognized that deregulation of Wnt signaling leads to cancer [4]. Given the tight association between Wnt signaling and cancer proliferation, apoptosis, and cancer stemness, Wnt signaling is thought associated with cancer radioresistance [5]. In this review, we discuss the close correlation between Wnt signaling and radioresistance and the mechanism by which Wnt signaling promotes radioresistance.

\section{Mechanisms of radioresistance}

Ionizing irradiation (IR) induces cancer cell death via a series of processes. First, it induces water radiolysis, thereby generating ROS. Then oxygen provides unpaired electrons for radicals within the DNA molecule, resulting in the stabilization of IR-induced DNA damage. Damaged DNA or excessive ROS activates apoptotic signaling pathways in cancer cells, leading to cell death [6] (Fig. 1). The success or failure of standard clinical radiation treatment is determined by the 4 R's of radiobiology: repair of DNA damage, redistribution of the cell cycle, repopulation of tumors, and reoxygenation of hypoxic tumor areas [7]. Thus, according to the process of IR-induced cell death, we conclude that radioresistant cancer cells protect themselves from IR by reducing ROS-induced damage including hypoxia, activity of the anti-oxidant system, and ROS scavengers, thereby enhancing DNA repair and increasing DNA damage tolerance mainly by activating intracellular pro-survival and antiapoptotic signaling pathways (Fig. 1).

\section{Wnt signaling pathway}

Wnt was first identified in 1982 [8]. Since then, an increasing amount of attention has focused on its functions. Wnt signaling is a key regulator of complex processes such as embryonic development, stem cell maintenance, tissue homeostasis, and wound healing. It is also closely associated with tumorigenesis. Wnt proteins are cysteine-rich and lipidmodified (palmitoylation). Palmitoylation is necessary for Wnt secretion, which is mediated by Porcupine enzyme in the endoplasmic reticulum. The palmitoylationmodified Wnt binds to Wingless multi-pass transmembrane protein in the Golgi, which transports Wnt to the plasma membrane and promotes Wnt secretion. Secreted Wnts can function in a paracrine and autocrine manner over a short distance of multiple cell diameters [9]. In addition, Wnts can spread over a long distance, despite their high hydrophobicity. There are two main hypotheses regarding how Wnts travel through the extracellular environment. One is that Wnt binds to the soluble secreted Wingless-interacting protein, which functions as an extracellular carrier for Wnt [10]. The second is that Wnts are transported on exosomes [11].

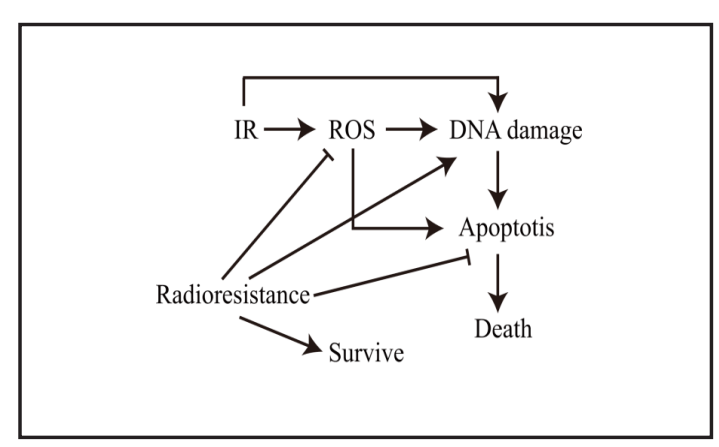

Fig. 1. Mechanisms of radioresistance. In response to IR, ROS is elevated and elevated ROS or IR then leads to DNA damage. When damaged DNA or excessive ROS is greater than the toxic threshold, the apoptotic signaling pathway in cancers is activated, causing cell death. Thus, radioresistant cells may protect themselves from IR-induced damage by three possible methods: inhibiting ROS generation, promoting DNA damage repair, and antagonizing the apoptotic signaling pathway after IR treatment. 
Secreted Wnt binds to its receptors Frizzled (Frz) and low-density lipoprotein receptorrelated 5/6 (LRP5/6), inducing activation of canonical and non-canonical Wnt signaling pathways. Because most studies have focused on canonical Wnt signaling, which is more clearly understood than non-canonical Wnt signaling, we discuss only canonical Wnt signaling in this review. When Frz/LRP receptors are not engaged, casein kinase 1 (CK1) and glycogen synthase kinase 3 (GSK3) sequentially phosphorylate Axin-bound $\beta$-catenin, which results in the ubiquitination of $\beta$-catenin by $\beta$-transducin repeats-containing proteins. Subsequently, $\beta$-catenin is targeted for rapid destruction by the proteasome, preventing it from entering the nucleus [9]. When Wnts bind with their receptors, Axin and the cytoplasmic phosphoprotein Dishevelled are recruited to induce LRP6 phosphorylation [12], which promotes Axin recruitment and $\beta$-catenin stabilization, thereby destroying the multiprotein destruction complex consisting of Axin, adenomatous polyposis coli protein, CK1 $\alpha$, and GSK3 $\beta$. Stabilized $\beta$-catenin enters the nucleus, promoting multi-target gene transcription. Thus, Wnt signaling inhibits $\beta$-catenin ubiquitination instead of suppressing $\beta$-catenin phosphorylation. In this way, the destruction complex is saturated by phosphorylated $\beta$-catenin and newly synthesized $\beta$-catenin enters into the nucleus [13]. However, the mechanisms underlying $\beta$-catenin shuttling between the cytoplasm and nucleus have been a subject of debate. Although the results of many recent studies suggest that increased cytoplasmic levels of $\beta$-catenin lead to nuclear entry [9], it has been shown that low levels of $\beta$-catenin are also sufficient for $\beta$-catenin relocalization [14]. Thus, further studies are needed on this issue. Once $\beta$-catenin enters the nucleus, it displaces Groucho and binds to lymphoid enhancer-binding factor/T-cell factor (LEF/TCF) proteins and other co-activators including B-cell lymphoma 9 protein, tissue-specific transcriptional activators, and histone modifiers such as BRG1, CREB-binding protein/p300, translocon-associated protein, MLL1/ MLL2, and SWR1, which cooperate to promote the activation of Wnt signaling (Fig. 2) [15].

Although it is known that cancer cells play essential roles in cancer development, it is now well recognized that they require the support of cancer-associated fibroblasts. Endothelial cells, immune cells, adipocytes, or fibroblasts are recruited to establish tumor microenvironments, which cooperate with cancer cells to maintain most cancer hallmarks [16]. There is extensive crosstalk between cancer cells and stromal cells; Wnts function as mediators of cell-cell communication and are strictly regulated by the tumor microenvironment. For example, breast cancer cells secrete Wnt7a, which recruits and activates fibroblasts [17]. In response to Wnt3a secretion by breast cancer cells, mature adipocytes transform into adipocytederived fibroblasts through activation of the $\mathrm{Wnt} / \beta$ catenin signaling pathway [18]. In addition, Wnts secreted by stromal cells affect cancer cells. Activated fibroblasts can directly secrete Wnt10B, which promotes endometrial cancer cell metastasis [19] or secretion of exosomes associated with cancer cell-

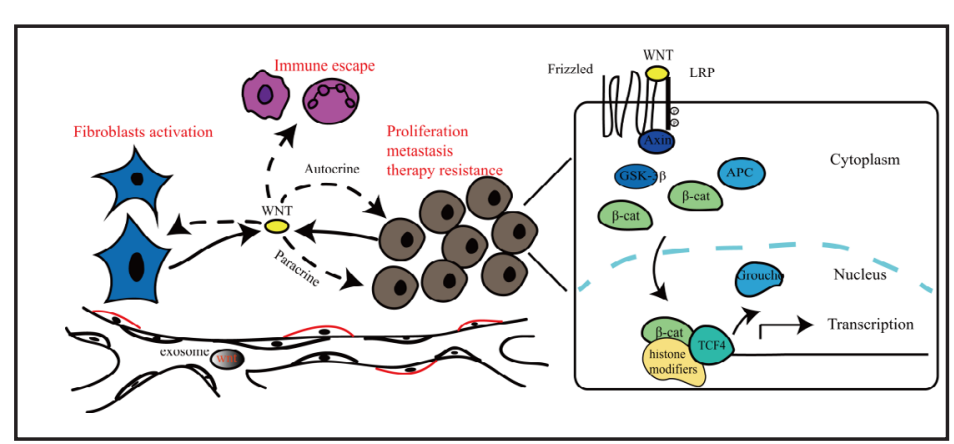

Fig. 2. Activation of the Wnt signaling pathway. Wnts function as mediators between cancer cells and stromal cells, which promotes fibroblast activation, immune evasion, and cancer proliferation and metastasis, and resistance to various treatments. Secreted Wnts by cancer cells and stromal cells function in paracrine and autocrine manners over short distances or in the form of exosomes over long distances. When Wnt binds to the Frz/LRP receptor, Dvl and Axin are recruited to bind to phosphorylated LRP. Once the destruction complex falls apart, $\beta$-catenin is stabilized. Stabilized $\beta$-catenin enters the nucleus and displaces Groucho and binds to LEF/TCF proteins and other co-activators including histone modifiers that cooperate to promote activation of Wnt signaling. 
derived Wnts to activate the Wnt/planar cell polarity pathway in cancer cells [20]. In the tumor microenvironment, Whts always associate with other chemokines or growth factors to promote cancer progression. For example, the Wnt pathway is preferentially activated in tumor cells located close to stromal myofibroblasts, due to the fact that myofibroblastsecreted factors and hepatocyte growth factor activate $\beta$-catenin-driven transcription in CSCs [21]. Activation of Wnt/Ror2 signaling in mesenchymal stem cells promotes gastric cancer cell proliferation by stimulating the secretion of C-X-C motif ligand 16 (CXCL16), which activates CXCL16/CXCR6 signaling in cancer cells [22]. Wnts, as important messengers, shuttle between cancer cells and stromal cells to promote cancer cell proliferation, invasion, metastasis, and cancer resistance to various treatments including radiation and drugs.

\section{Wnt signaling induces radioresistance}

Active Wnt signaling induces radioresistance in several human cancers including head and neck, breast, nasopharyngeal, esophageal, glioblastoma, and colorectal cancers [2328]. Here, we introduce the mechanisms of Wnt-induced radioresistance in detail. IR not only induces changes in cancer cells, but also remodels the tumor microenvironment. The coordination between cancer cells and the tumor microenvironment is necessary for radiation efficiency. The stroma plays a crucial role in determining the outcome of radiotherapy. Irradiated stromal cells promote cancer cell proliferation [29]. IR induces the expression of a wide spectrum of secreted cytokines and growth factors that strengthen the communication between cancer cells and stromal cells [30]. Wnts, as previously described, are important mediators of shuttling between these two cell types. It has been demonstrated that IR can induce Wnt secretion by both cancer cells and stromal cells. Enhanced Wnt expression in cancer by IR underlies the relationship between Wnts and acquired radioresistance. For example, IR-induced Wnt16B secretion by fibroblasts promotes the epithelial-mesenchymal transition (EMT) in prostate cancer cells and resistance to IR [30]. In addition, IR upregulates Wnt2B expression in nasopharyngeal cancer cells, which functions in autocrine signaling. Whts are also involved in the communication among stromal cells. For example, IR-induced upregulation of Wnt16B in fibroblasts activates the canonical Wnt signaling pathway in dendritic cells and regulates the differentiation of regulatory $\mathrm{T}$ cells, thus inducing cancer immune evasion [31].

In addition to the upregulation of Wnt protein by IR, several other factors function as Wht signaling co-activators that induce radioresistance. For example, in response to DNA damage, proliferating cell nuclear antigen (PCNA)-associated factor PAF is segregated from PCNA and then recruits enhancer of zeste homolog 2 to the $\beta$-catenin transcriptional complex, thereby promoting Wnt signaling hyperactivation [32]. In retinoblastoma cells, telomerase is activated by damaged DNA [33]. Telomerase interacting with BRG1 binds to chromatin sites on the promoters of $\beta$-catenin-targeted genes [34]. So, there are similarities in gene expression regulation by telomerase and Wnt [35]. To sum up, after IR, Wnts and many other co-activators are induced in both cancer cells and stromal cells, which coordinate to protect cancer cells from IR-induced damage. Thus, to improve the efficiency of radiation, Wnt signaling may be an appropriate target.

\section{Wnt signaling is associated with CSCs and EMT and promotes radioresistance}

Multiple studies have suggested that CSCs have self-renewal capacity and multidifferentiation potential, which distinguishes them from non-tumorigenic cells with CSCspecific markers [36]. It is generally accepted that CSCs are tightly linked with tumor aggressiveness and treatment response, and that eliminating CSCs could cure cancer [1]. Because CSCs have advantages such as enhanced DNA repair capacity, high expression of ROS scavengers, and activation of anti-apoptotic signaling, they are thought to be closely 
associated with tumor radioresistance [37]. After exposure to IR, breast CSCs had lower levels of ROS concomitant with the increased expression of anti-oxidant systems such as glutathione S-transferase, which contributed to tumor radioresistance [38]. Activation of the DNA damage response (DDR) in glioma stem cells promotes radioresistance by preferential checkpoint activation of checkpoint kinase 1/2 (Chk1/2) [39]. In addition to intrinsic CSCs, non-stem cancer cells (NSCCs) may dedifferentiate into CSCs in response to IR, which contributes to the relapse and metastasis of cancer [40]. In 2012, Lagadec et al. observed that IR induced the enrichment of breast CSCs via promotion of stem cell-like properties in NSCCs [41]. These results were also demonstrated by Ghisolfi et al. in hepatocellular carcinoma cells [42] and by Wang et al. in breast cancer cells [42, 43]. Thus, CSCs are involved in both intrinsic and acquired radioresistance.

EMT is a developmental process that naturally occurs in the developing embryo [4446]. It also plays an essential role in cancer invasion and metastasis. Cells undergoing EMT exhibit acquisition of mesenchymal traits with the upregulation of $\mathrm{N}$-cadherin, vimentin, and transcriptional factors including Snail, Slug, zinc finger E-box-binding homeobox 1 (ZEB1), and ZEB2. There is also a close link between EMT and cancer cell stemness; cells undergoing EMT have the ability to express stem cell markers, thus maintaining the stem cell state [47, 48]. It is well known that cells resist chemotherapy during EMT [49], so it is reasonable for cells to resist other types of damage including IR damage through EMT. For example, Snail and Slug inhibit p53-mediated apoptosis in response to IR, whereas ZEB1 promotes IR-induced DNA damage repair $[50,51]$. Wnt/ $\beta$-catenin signaling is implicated in IRinduced cancer stemness and EMT. Cancer stemness is not a rigid trait but can be modulated by the Wnt signaling pathway, which controls self-renewal and the multi-differentiation capacity of CSCs [21]. It has been suggested that after IR, Wnt helps to regenerate tissue and Wnt5a promotes glioblastoma stem cell differentiation [52-54]. The close link between Wht signaling, cancer stemness, and EMT may be one mechanism underlying Wnt-induced radioresistance. For example, $\beta$-catenin/TCF upregulates aldehyde dehydrogenase, contributing to radioresistance of prostate cancer progenitor cells [55]. In addition, loss of Wnt signaling impairs recovery of CRCs from IR injury including elevated ROS and doublestranded DNA breaks (DSBs) [56].

\section{ROS}

IR-induced ROS production is one of the key determinates of IR-induced cell death. High levels of ROS cause irreversible damage to cellular components such as proteins, nucleic acids, and lipids, which induces cell death. However, low levels of ROS, acting as second messengers, promote cancer proliferation and metastasis. To maintain ROS levels below the toxic threshold after IR is an important determinate of radiotherapy outcome [56]. ROS scavengers help clear excessive ROS in cancer cells to avoid ROS-induced DNA damage and sustain its oncogenic role. Thus, ROS are thought to be key mediators of radioresistance. It was reported that in the absence of $\beta$-catenin, expression of the hydrogen peroxide detoxifying enzyme catalase (CAT) was decreased and ROS levels were increased in cells after IR treatment, demonstrating that the Wnt signaling pathway plays a role in the regulation of oxidative stress [56]. $\beta$-catenin can protect against oxidative stress by controlling the balance between the TCF signaling pathway (mainly proliferative) and the forkhead box 0 (FOXO) signaling pathway (mainly stress response). The FOXO family of transcription factors regulates a variety of cellular programs including ROS scavenging via induction of antioxidant proteins such as manganese superoxide dismutase, CAT, and growth arrest and DNA damage-inducible gene 45. Cells are protected from ROS damage induced by IR through the upregulation of FOXO. For example, it was reported that FOXO promoted glioblastoma stem cell survival after IR [57]. Under oxidative stress, $\beta$-catenin regulates FOXO, and its binding to FOXO increases under conditions of oxidative stress. However, when ROS levels are controlled and are no longer toxic, $\beta$-catenin may regain binding with TCF, thus promoting cancer cell proliferation.

\section{KARGER}




\section{DNA damage repair}

IR generates various types of DNA damage including single-stranded DNA breaks and DSBs, the most toxic of which are DSBs. Components of DDR are considered to be biomarkers of radiosensitivity [58]. If damaged DNA cannot be removed or repaired, DDR can trigger cell death. The DDR is activated in the presence of DNA lesions. The DDR occurs in three steps: recognition of DNA damage lesions, signal transduction, and DNA damage repair [59]. In the process of DSB repair, MRE11/RAD50/NBS1 and telomeric repeat-binding factor 2 recognize DSBs and then recruit ataxia telangiectasia mutated serine-protein kinase (ATM), ataxia telangiectasia and Rad3 related protein kinase (ATR), and DNA-dependent protein kinase, catalytic subunits (DNA-PKcs) to amplify and transduce damage signals to downstream effectors. In addition, chromatins are always remodeled to facilitate accessibility of the repair machinery. For example, ATM/ATR/DNA-PKcs mediate phosphorylation of serine 139 of the histone $\mathrm{H} 2 \mathrm{~A}$ variant, H2AX, on chromatin-flanking DSB sites. This causes ubiquitin adduct formation in such regions, after which DDR factors are recruited to promote DSB repair [60]. After receiving DNA damage signals, DNA repair pathways such as the p53 signaling pathway are activated. DSBs are repaired by two major pathways: homologous recombination (HR) and non-homologous end joining (NHEJ) (Fig. 3). HR always occurs in the G2 and S phases, whereas NHEJ is cycle-independent. RAD51, RAD51/B/C/D, breast cancer type 1 (BRCA1), BRCA2, X-ray repair cross complementing 2 (XRCC2), and XRCC3 are responsible for HR, whereas KU70 (XRCC6), KU80 (XRCC5), DNA-PKcs, DNA ligase IV (LIG4), and XRCC4 are involved in NHEJ [61]. Both

HR and NHEJ machineries repair DSBs, and the choice of the appropriate DSB repair pathway is key to maintaining genome stability. NHEJ is the only choice in the G1 phase when phosphorylated 53P1 recruits replication timing regulatory factor 1 (RIF1) to DSB sites to prevent 5' end resection. When cells enter the $S$ phase, BRCA1 interacts with ubiquitin-like with PHD and ring finger domains 1 to remove RIF1 from DSB sites, ultimately promoting HR.

\section{DNA damage check- point responses}

The DDR is always accompanied by the decrease or arrest of the cell cycle, which increases the time available for DNA repair. Preferential checkpoint activation like Chk1/2, ATM, and ATR is necessary for cancer cells

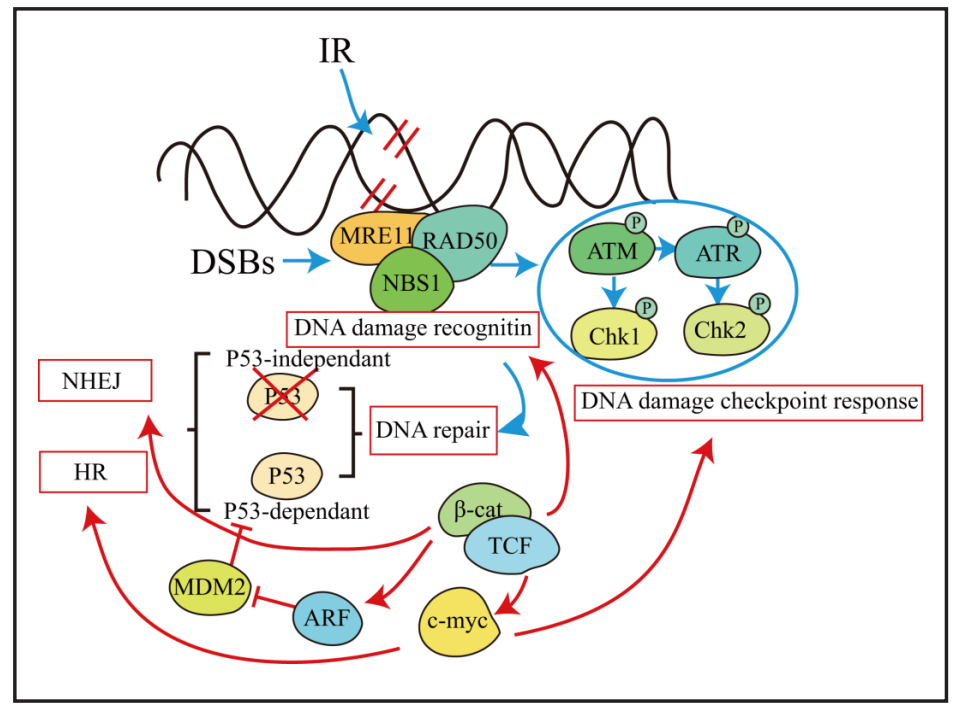

Fig. 3. Wnt-induced DNA damage repair. IR-induced DSBs activate the DDR in cancer cells: DNA damage recognition, DNA damage checkpoint response, and DNA repair mainly including NHEJ and HR. MRE11/ RAD50/NBS1 functions as DSB sensors, recruiting ATM and ATR, which activate the DNA damage checkpoint response. DNA repair is then activated in both p53-dependent and p53-independent manners. Active Wnt signaling is involved in each step of the DDR. $\beta$-catenin upregulates MRE11 expression, which promotes DNA damage recognition. Wnt signaling targeted genes c-Myc activates ATM and Chk1/2, thus activating the DNA damage checkpoint response. Furthermore, $\beta$-catenin upregulates ARF, which binds to and inactivates MDM2, leading to the activation of p53. In addition, active Wnt signaling upregulates NHEJrelated proteins including LIG4, KU70, and KU80 and c-Myc promotes HR-related protein expression such as RAD51. 
to induce cell-cycle arrest to repair damaged DNA. Thus, regulation of the cell cycle is an essential part of the DDR. The ability of Wnt signaling to coordinate cell cycle progression and DNA damage repair determinates radiosensitivity of cancer cells. However, downstream targets of the $\beta$-catenin/TCF signaling pathway including c-Myc and cyclin D1 stimulate cell cycle progression, which antagonizes DNA damage checkpoint responses. It is necessary for $\beta$-catenin to coordinate DNA damage repair and cell cycle progression. To solve this contradiction, Wht signaling may experience a series of changes to make it optimal for cell survival. There are two possible explanations. The first is that c-Myc promotes cell cycle progression. However, under genotoxic stress, genes transcriptionally activated by c-Myc tend to be DNA damage checkpoint kinase such as Chk1/2, which induces cell cycle arrest [62] (Fig. 3). In addition, upon exposure to IR, c-Myc plays a crucial role in the activation of ATM checkpoints [63]. Another explanation is totally contrary to the first, namely, that the proliferative role of Wnt signaling is temporally inhibited in response to IR by three possible manners. First is the temporal degradation of $\beta$-catenin. p53, as an important component of DNA repair system, is always activated in response to DNA damage agents. p53 plays an important role in degrading $\beta$-catenin. p53 could promote seven in absentia homolog 1 (SIAH1) expression. Then $\beta$-catenin is degraded by SIAH1, which induces cell cycle arrest contributing to DNA repair [64]. The second possibility is the disconnection of $\beta$-catenin from TCF-4, which is regulated by DNA damage recognition. Under normal circumstances, poly(ADP-ribose) polymerase-1 (PARP-1) binds to $\beta$-catenin, activating the $\beta$-catenin/TCF signaling pathway. In response to DNA damage, PARP-1 polyADP-ribosylates its own automodification domain, which leads to its disassociation from TCF and allows KU70 interaction with TCF-4. The interaction between KU70 and TCF-4 disrupts the association between $\beta$-catenin and TCF-4, thus inhibiting c-Myc transcription [65]. In addition, multiple molecular events can compete with TCF-4 and LEF-1 interaction with $\beta$-catenin. In response to hypoxia, $\beta$-catenin preferentially interacts with hypoxia inducible factor 1 alpha (HIF-1 $\alpha$ ) compared with TCF-4. As a result, HIF-1 $\alpha$-targeted genes are upregulated and c-Myc and cyclin D1 are downregulated [66]. FOXO, another TCF-4 competitor, is also involved in separating $\beta$-catenin from TCF-4. The $\beta$-catenin/FOXO signaling pathway inhibits cell cycle progression through the upregulation of p27kip1 and p130 and the downregulation of cyclin D1 $[67,68]$. Thus, $\beta$-catenin plays a crucial role in balancing the positive (through TCF) and negative (through FOXO) regulation of cell cycle progression under conditions of radiation, and the transition is partly regulated by DNA damage recognition systems. The third possibility is occurrence of the adjustment of promoter selectivity by $\beta$-catenin-TCF-4. In the process of DNA damage repair, c-Myc and cyclin D1 may be inhibited while DNA repair-promoting genes are activated transcriptionally. It is demonstrated that $\beta$-catenin/LEF- 1 upregulates Mre11 expression, which induces DNA damage recognition upon exposure to IR [69]. However, inhibition of Wht signaling in promoting proliferation is temporal. Upon the completion of DNA damage repair, the $\beta$-catenin/TCF signaling pathway would be reactivated and cancer cells resume proliferation, which induces the failure of radiotherapy.

\section{p53-dependent and p53-independent DNA repair pathway}

Extensive crosstalk exists between p53, a classical DNA damage repair regulator, and the Wnt/ $\beta$-catenin signaling pathway, primarily through the actions of their target genes. Stabilization of $\beta$-catenin by the Wnt signaling pathway results in upregulation of the ADP ribosylation factor (ARF) tumor suppressor protein, which leads to the inactivation of mouse double minute 2 homolog (MDM2). Because MDM2 plays a role in degrading p53, MDM2 inactivation triggers the cellular p53 response. However, p53 is always mutant in cancer cells; thus, the p53-independent DNA repair pathway seems necessary for DNA damage repair in cancer. It is well recognized that $\beta$-catenin, a crucial transcriptional factor, controls multiple gene expression including DNA repair-related genes. $\beta$-catenin is involved in both NHEJ and 
HR machineries. For example, $\beta$-catenin promotes LIG4 expression in a p53-independent manner [5], thus promoting the NHEJ-mediated repair of DSBs. $\beta$-catenin also upregulates KU70/KU80 by regulating cyclooxygenase 2 and AMP-activated protein kinase in response to IR [70]. C-Myc, an important $\beta$-catenin-targeted gene, is involved in DSB repair. The chromatin immunoprecipitation assay has demonstrated that c-Myc binds to the promoters of several HR- and NHEJ-related genes including RAD51, BRCA1, BRCA2, DNA-PKcs, XRCC4, KU70, and LIG4. However, only RAD51 is regulated by c-Myc [71] (Fig. 3).

\section{Apoptosis}

Even though damaged DNA is not repaired successfully, there is still a final barrier to resist cell death. Radioresistant cancer cells can increase their tolerance to DNA damage by elevating the toxicity threshold by such actions as downregulating apoptotic signaling pathways and upregulating pro-survival signaling pathways. Resisting apoptosis, a hallmark of cancer, is an important obstacle to various anti-cancer treatments. Apoptotic signaling pathways mainly comprise intrinsic and extrinsic signaling pathways. The intrinsic apoptotic signaling pathway mainly integrates various signals in cancers, triggering cytochrome c release from the mitochondria, after which caspase 9 is activated. The extrinsic apoptotic signaling pathway, however, recognizes and transduces extracellular death signals such as Fas and TNF-related apoptosis-inducing ligand (TRAIL) through Fas ligand and death receptor 5 (DR5), respectively, ultimately activating caspase 8 . Then a proteolysis cascade is initiated and caspase 3 is activated to execute apoptosis [72]. B-cell lymphoma 2 (Bcl2) family members, as important apoptosis regulators, are involved in the determining the fate of cancer cells (death or survival). Bcl-2 family members mainly include pro-apoptotic proteins such as Bax and Bak, anti-apoptotic family members, and BH3-only proteins. Antiapoptotic Bcl-2 proteins bind to pro-apoptotic proteins to inhibit them, disrupting the integrity of the outer mitochondrial membrane and the release of cytochrome c. However, BH3-only proteins promote apoptosis by interfering with the interaction between antiapoptotic proteins or facilitating the interaction of pro-apoptotic Bcl-2 family members [72, 73].

Upon exposure to IR, levels of ROS and damaged DNA are always elevated. When they are increase above the toxicity threshold, apoptosis is initiated. IR-induced apoptosis involves both intrinsic and extrinsic apoptotic signaling pathways. Several studies have suggested that Fas and FasL, TRAIL, and DR5 are induced by IR [74-77]. Bcl-2 family members, as key modulator of the intrinsic apoptotic signaling pathway, also play an important role in IR-induced apoptosis. For example, the ratio between Bcl-2 and Bax levels determine the sensitivity of cancers to IR [78]. p53 is not only involved in DNA repair, but is also involved in apoptosis. If damaged DNA cannot be completely repaired, p53 may trigger apoptotic signaling pathways in cancer by upregulating the BH3-only proteins Noxa and Puma [51]. However, the pro-survival and anti-apoptosis signaling pathways in cancers compete with apoptotic signaling pathways to help resist apoptosis, which finally increases the death threshold, providing more time for cancers to clear excessive ROS and repair damaged DNA. The Wnt/ $\beta$-catenin signaling pathway, as a pro-survival signaling pathway, creates extensive crosstalk with other pro-survival signaling pathways such as phosphoinositide 3-kinase (PI3K)/Akt, mitogen-activated protein kinase, and signal transducer and activator of transcription (STAT) signaling pathways. Upon exposure to IR, pro-survival signaling pathways protect cancer cells from IR-induced damage. It is well recognized that PI3K/ Akt signaling promotes activation of Wnt signaling via inhibition of GSK-3 $\beta$. At the same time, Wnt signaling interferes with PI3K/Akt signaling [79]. Resistance reversal with PI3K/ Akt inhibitor and Wnt signaling inhibitors demonstrates the coordination between PI3K/ Akt and Wnt signaling [80]. In addition, on one hand, STAT3 is involved in the activation of Wnt signaling in colorectal cancer [81]. On the other hand, STAT3 is transactivated by the $\beta$-catenin/TCF complex [82]. All of these reports demonstrate the tight correlation between 
Wnt signaling and other pro-survival signaling pathways. Given the crosstalk among these pro-survival signaling pathways, combination therapy seems necessary.

Wnt signaling is implicated in the regulation of apoptosis [4]. The association between Wnt signaling and apoptotic signaling has been identified in multiple studies. For example, some apoptotic stimuli promote cancer apoptosis by antagonizing Wnt-mediated survival signaling by cleaving $\beta$-catenin [83]. FAS-associated factor 1 , a component of the Fas deathinducing signaling complex, promotes apoptosis by degrading $\beta$-catenin [52]. On the other hand, Wnt signaling impacts apoptotic components. It has been demonstrated that Wnt1 signaling inhibits cancer therapy-induced apoptosis by inhibiting cytochrome c release and activation of caspase- 9 [84]. In addition, inhibition of $\beta$-catenin in head and neck squamous cell carcinoma (HNSCC) induced the activation of caspase-3, increased p53 and the proapoptotic protein Bax, and reduced the anti-apoptotic protein Bcl-2 [86]. Wnt-1-induced secreted protein, as an important downstream target gene of Wnt $1 / \beta$-catenin signaling, prevents p53-mediated apoptosis, inhibits the mitochondrial release of cytochrome $c$, and elevates the expression of anti-apoptotic protein Bcl- $\mathrm{X}_{\mathrm{L}}$ in cancer [52]. Also, Wnt signaling promotes survivin expression in colon cancer [85]. Thus, the close link between Wnt and apoptotic signaling demonstrates that Wnt signaling plays a crucial role in the regulation of apoptosis.

\section{Conclusion}

Given the pivotal role of radiotherapy for some cancers like head and neck and esophageal SCC, radiosensitization has garnered an increasing amount of interest. In phase 3 clinical trials, radiation in combination with the molecular-targeted epidermal growth factor receptor (EGFR) inhibitor cetuximab led to a survival benefit of $10 \%$ in patients with HNSCC [3]. Delayed EGFR nuclear accumulation by downregulation of caveolin-1 increased radiosensitivity in breast cancer [86]. In preclinical models, PI3K/mTOR inhibitor enhances HNSCC radiosensitivity [87]. Thus, exploring molecular-targeted modifiers associated with radiosensitivity is warranted. Multiple lines of evidences have demonstrated that Wnt signaling may be a target for radiosensitization. Upon exposure to IR, Wnt signaling is activated and protects cells from death by promoting ROS scavenging and DNA damage repair, and inhibiting apoptosis. Thus, it is reasonable that combining radiation and Wnt signaling inhibitors may attenuate IR-induced Wnt signaling activation. At the same time, Wnt inhibitors attenuate IR-induced EMT and stem properties acquisition, thus promoting cell death after IR. Above all, Wnt signaling is an important protective mechanism for cells in response to IR, and targeting the Wnt signaling pathway may be a useful strategy for increasing radiosensitivity. Table 1 lists some of the small molecules that inhibit the Wnt pathway. As examples, iCRT14 enhances radiosensitivity in colon cancer [5] and FH535 promotes esophageal cancer radiosensitization [88]. These data illustrate that Wnt signaling is a good target for radiosensitization, and that a Wnt signaling inhibitor may be appropriate to test in future clinical trials.

Table 1. Small-molecule Wnt pathway inhibitors

\begin{tabular}{cccc}
\hline Small molecule & Molecular Target & Function & Reference \\
\hline LGK974 & Porcupine & Inhibitor & (Jun Liu et al, 2013) [89] \\
C59 & Porcupine & Inhibitor & (Bon-Kyoung Koo et al, 2015) [90] \\
XAV939 & Axin & Stabilizes Axin & (Huang SM et al, 2009) [91] \\
K-756 & Axin & Stabilizes Axin & (Ryoko Okada-Iwasaki et al, 2016) [92] \\
CWP232228 & TCF/ $\beta$-catenin & Inhibitor & (Gyu-Beom Jang et al., 2015) [93] \\
iCRT & TCF/ $\beta$-catenin & Inhibitor & (Foster C. Gonsalves et al, 2011) [94] \\
Pyrvinium & CK1 & Activates CK1 & (Curtis A Thorne et al, 2010) [95] \\
\hline
\end{tabular}




\section{Cellular Physiology Cell Physiol Biochem 2018;48:419-432 \begin{tabular}{l|l} 
DOI: 10.1159/000491774 & O 2018 The Author(s). Published by S. Karger AG, Basel \\
www.karger.com/cpb
\end{tabular} \\ Zhao et al.: Wnt-Induced Cancer Radioresistance}

\section{Acknowledgements}

This work was supported by the Jiangsu Natural Science Foundation of China (no. BK20161387).

We thank Jun Yi, the host of the foundation BK20161487, for his many good ideas on this review.

\section{Disclosure Statement}

The authors have no competing interests.

\section{References}

1 Skvortsova I, Debbage P, Kumar V, Skvortsov S: Radiation resistance: Cancer stem cells (CSCs) and their enigmatic pro-survival signaling. Semin Cancer Biol 2015;35:39-44.

-2 Rycaj K, Tang DG: Cancer stem cells and radioresistance. Int J Radiat Biol 2014;90:615-621.

3 Bonner JA, Harari PM, Giralt J, Azarnia N, Shin DM, Cohen RB, Jones CU, Sur R, Raben D, Jassem J, Ove R, Kies MS, Baselga J, Youssoufian H, Amellal N, Rowinsky EK, Ang KK: Radiotherapy plus cetuximab for squamouscell carcinoma of the head and neck. N Engl J Med 2006;354:567-578.

-4 Polakis P: Wnt signaling in cancer. Cold Spring Harb Perspect Biol 2012;4:

-5 Jun S, Jung YS, Suh HN, Wang W, Kim MJ, Oh YS, Lien EM, Shen X, Matsumoto Y, McCrea PD, Li L, Chen J, Park JI: LIG4 mediates Wnt signalling-induced radioresistance. Nat Commun 2016;7:10994.

6 Rey S, Schito L, Koritzinsky M, Wouters BG: Molecular targeting of hypoxia in radiotherapy. Adv Drug Deliv Rev 2017;109:45-62.

7 Good JS, Harrington KJ: The hallmarks of cancer and the radiation oncologist: updating the 5Rs of radiobiology. Clin Oncol (R Coll Radiol) 2013;25:569-577.

$>8$ Nusse R, Varmus HE: Many tumors induced by the mouse mammary tumor virus contain a provirus integrated in the same region of the host genome. Cell 1982;31:99-109.

-9 Clevers H, Nusse R: Wnt/beta-catenin signaling and disease. Cell 2012;149:1192-1205.

-10 Mulligan KA, Fuerer C, Ching W, Fish M, Willert K, Nusse R: Secreted Wingless-interacting molecule (Swim) promotes long-range signaling by maintaining Wingless solubility. Proc Natl Acad Sci U S A 2012;109:370377.

11 Gross JC, Chaudhary V, Bartscherer K, Boutros M: Active Wnt proteins are secreted on exosomes. Nat Cell Biol 2012;14:1036-1045.

12 Shimizu N, Ishitani S, Sato A, Shibuya H, Ishitani T: Hipk2 and PP1c cooperate to maintain Dvl protein levels required for Wnt signal transduction. Cell Rep 2014;8:1391-1404.

13 Li VS, Ng SS, Boersema PJ, Low TY, Karthaus WR, Gerlach JP, Mohammed S, Heck AJ, Maurice MM, Mahmoudi T, Clevers H: Wnt signaling through inhibition of beta-catenin degradation in an intact Axin1 complex. Cell 2012;149:1245-1256.

14 Goentoro L, Kirschner MW: Evidence that fold-change, and not absolute level, of beta-catenin dictates Wnt signaling. Mol Cell 2009;36:872-884.

15 Willert K, Jones KA: Wnt signaling: is the party in the nucleus? Genes Dev 2006;20:1394-1404.

-16 Giannoni E, Bianchini F, Calorini L, Chiarugi P: Cancer associated fibroblasts exploit reactive oxygen species through a proinflammatory signature leading to epithelial mesenchymal transition and stemness. Antioxid Redox Signal 2011;14:2361-2371.

17 Avgustinova A, Iravani M, Robertson D, Fearns A, Gao Q Klingbeil P, Hanby AM, Speirs V, Sahai E, Calvo F, Isacke CM: Tumour cell-derived Wnt7a recruits and activates fibroblasts to promote tumour aggressiveness. Nat Commun 2016;7:10305.

18 Bochet L, Lehuede C, Dauvillier S, Wang YY, Dirat B, Laurent V, Dray C, Guiet R, Maridonneau-Parini I, Le Gonidec S, Couderc B, Escourrou G, Valet P, Muller C: Adipocyte-derived fibroblasts promote tumor progression and contribute to the desmoplastic reaction in breast cancer. Cancer Res 2013;73:5657-5668. 


\section{Cellular Physiology Cell Physiol Biochem 2018;48:419-432

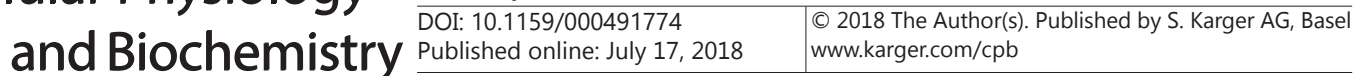

19 Aprelikova O, Palla J, Hibler B, Yu X, Greer YE, Yi M, Stephens R, Maxwell GL, Jazaeri A, Risinger JI, Rubin JS, Niederhuber J: Silencing of miR-148a in cancer-associated fibroblasts results in WNT10B-mediated stimulation of tumor cell motility. Oncogene 2013;32:3246-3253.

20 Luga V, Wrana JL: Tumor-stroma interaction: Revealing fibroblast-secreted exosomes as potent regulators of Wnt-planar cell polarity signaling in cancer metastasis. Cancer Res 2013;73:6843-6847.

-21 Vermeulen L, De Sousa EMF, van der Heijden M, Cameron K, de Jong JH, Borovski T, Tuynman JB, Todaro M, Merz C, Rodermond H, Sprick MR, Kemper K, Richel DJ, Stassi G, Medema JP: Wnt activity defines colon cancer stem cells and is regulated by the microenvironment. Nat Cell Biol 2010;12:468-476.

-22 Takiguchi G, Nishita M, Kurita K, Kakeji Y, Minami Y: Wnt5a-Ror2 signaling in mesenchymal stem cells promotes proliferation of gastric cancer cells by activating CXCL16-CXCR6 axis. Cancer Sci 2016;107:290297.

23 Li G, Liu Y, Su Z, Ren S, Zhu G, Tian Y, Qiu Y: MicroRNA-324-3p regulates nasopharyngeal carcinoma radioresistance by directly targeting WNT2B. Eur J Cancer 2013;49:2596-2607.

24 Zhou S, Ye W, Ren J, Shao Q, Qi Y, Liang J, Zhang M: MicroRNA-381 increases radiosensitivity in esophageal squamous cell carcinoma. Am J Cancer Res 2015;5:267-277.

25 Kendziorra E, Ahlborn K, Spitzner M, Rave-Frank M, Emons G, Gaedcke J, Kramer F, Wolff HA, Becker H, Beissbarth T, Ebner R, Ghadimi BM, Pukrop T, Ried T, Grade M: Silencing of the Wnt transcription factor TCF4 sensitizes colorectal cancer cells to (chemo-) radiotherapy. Carcinogenesis 2011;32:1824-1831.

-26 Kim Y, Kim KH, Lee J, Lee YA, Kim M, Lee SJ, Park K, Yang H, Jin J, Joo KM, Lee J, Nam DH: Wnt activation is implicated in glioblastoma radioresistance. Lab Invest 2012;92:466-473.

-27 Chang HW, Roh JL, Jeong EJ, Lee SW, Kim SW, Choi SH, Park SK, Kim SY: Wnt signaling controls radiosensitivity via cyclooxygenase-2-mediated Ku expression in head and neck cancer. Int J Cancer 2008;122:100-107.

28 Chen MS, Woodward WA, Behbod F, Peddibhotla S, Alfaro MP, Buchholz TA, Rosen JM: Wnt/beta-catenin mediates radiation resistance of Sca1+ progenitors in an immortalized mammary gland cell line. J Cell Sci 2007;120:468-477.

29 Barcellos-Hoff MH, Ravani SA: Irradiated mammary gland stroma promotes the expression of tumorigenic potential by unirradiated epithelial cells. Cancer Res 2000;60:1254-1260.

30 Sun Y, Campisi J, Higano C, Beer TM, Porter P, Coleman I, True L, Nelson PS: Treatment-induced damage to the tumor microenvironment promotes prostate cancer therapy resistance through WNT16B. Nat Med 2012;18:1359-1368.

-31 Shen CC, Kang YH, Zhao M, He Y, Cui DD, Fu YY, Yang LL, Gou LT: WNT16B from ovarian fibroblasts induces differentiation of regulatory T cells through beta-catenin signal in dendritic cells. Int J Mol Sci 2014;15:12928-12939.

-32 Jung HY, Jun S, Lee M, Kim HC, Wang X, Ji H, McCrea PD, Park JI: PAF and EZH2 induce Wnt/beta-catenin signaling hyperactivation. Mol Cell 2013;52:193-205.

-33 Akiyama M, Ozaki K, Kawano T, Yamada O, Kawauchi K, Ida H, Yamada H: Telomerase activation as a repair response to radiation-induced DNA damage in Y79 retinoblastoma cells. Cancer Lett 2013;340:82-87.

34 Park JI, Venteicher AS, Hong JY, Choi J, Jun S, Shkreli M, Chang W, Meng Z, Cheung P, Ji H, McLaughlin M, Veenstra TD, Nusse R, McCrea PD, Artandi SE: Telomerase modulates Wnt signalling by association with target gene chromatin. Nature 2009;460:66-72.

-35 Choi J, Southworth LK, Sarin KY, Venteicher AS, Ma W, Chang W, Cheung P, Jun S, Artandi MK, Shah N, Kim SK, Artandi SE: TERT promotes epithelial proliferation through transcriptional control of a Myc- and Wnt-related developmental program. PLoS Genet 2008;4:e10.

-36 Cojoc M, Mabert K, Muders MH, Dubrovska A: A role for cancer stem cells in therapy resistance: cellular and molecular mechanisms. Semin Cancer Biol 2015;31:16-27.

-37 Butof R, Dubrovska A, Baumann M: Clinical perspectives of cancer stem cell research in radiation oncology. Radiother Oncol 2013;108:388-396.

-38 Diehn M, Cho RW, Lobo NA, Kalisky T, Dorie MJ, Kulp AN, Qian D, Lam JS, Ailles LE, Wong M, Joshua B, Kaplan MJ, Wapnir I, Dirbas FM, Somlo G, Garberoglio C, Paz B, Shen J, Lau SK, Quake SR, Brown JM, Weissman IL, Clarke MF: Association of reactive oxygen species levels and radioresistance in cancer stem cells. Nature 2009;458:780-783.

-39 Bao S, Wu Q, McLendon RE, Hao Y, Shi Q Hjelmeland AB, Dewhirst MW, Bigner DD, Rich JN: Glioma stem cells promote radioresistance by preferential activation of the DNA damage response. Nature 2006;444:756-760. 


\section{Cellular Physiology Cell Physiol Biochem 2018;48:419-432 \begin{tabular}{l|l} 
DOI: 10.1159/000491774 & $\begin{array}{l}\text { O } 2018 \text { The Author(s). Published by S. Karger AG, Basel } \\
\text { www.karger.com/cpb }\end{array}$
\end{tabular} \\ Zhao et al.: Wnt-Induced Cancer Radioresistance}

40 Li F, Zhou K, Gao L, Zhang B, Li W, Yan W, Song X, Yu H, Wang S, Yu N, Jiang Q: Radiation induces the generation of cancer stem cells: A novel mechanism for cancer radioresistance. Oncol Lett 2016;12:30593065.

41 Lagadec C, Vlashi E, Della Donna L, Dekmezian C, Pajonk F: Radiation-induced reprogramming of breast cancer cells. Stem Cells 2012;30:833-844.

42 Ghisolfi L, Keates AC, Hu X, Lee DK, Li CJ: Ionizing radiation induces stemness in cancer cells. PLoS One 2012;7:e43628.

-43 Wang Y, Li W, Patel SS, Cong J, Zhang N, Sabbatino F, Liu X, Qi Y, Huang P, Lee H, Taghian A, Li JJ, DeLeo AB, Ferrone S, Epperly MW, Ferrone CR, Ly A, Brachtel EF, Wang X: Blocking the formation of radiation-induced breast cancer stem cells. Oncotarget 2014;5:3743-3755.

44 Nawshad A, Lagamba D, Polad A, Hay ED: Transforming growth factor-beta signaling during epithelialmesenchymal transformation: implications for embryogenesis and tumor metastasis. Cells Tissues Organs 2005;179:11-23.

45 Kiefer JC, Nieto A, Thiery JP: Primer and interview: epithelial to mesenchymal transition [Interview by Julie Kiefer].. Dev Dyn 2008;237:2769-2774.

46 Peinado H, Portillo F, Cano A: Transcriptional regulation of cadherins during development and carcinogenesis. Int J Dev Biol 2004;48:365-375.

47 Mani SA, Guo W, Liao MJ, Eaton EN, Ayyanan A, Zhou AY, Brooks M, Reinhard F, Zhang CC, Shipitsin M, Campbell LL, Polyak K, Brisken C, Yang J, Weinberg RA: The epithelial-mesenchymal transition generates cells with properties of stem cells. Cell 2008;133:704-715.

48 Scheel C, Eaton EN, Li SH, Chaffer CL, Reinhardt F, Kah KJ, Bell G, Guo W, Rubin J, Richardson AL, Weinberg RA: Paracrine and autocrine signals induce and maintain mesenchymal and stem cell states in the breast. Cell 2011;145:926-940.

-49 Fischer KR, Durrans A, Lee S, Sheng J, Li F, Wong ST, Choi H, El Rayes T, Ryu S, Troeger J, Schwabe RF, Vahdat LT, Altorki NK, Mittal V, Gao D: Epithelial-to-mesenchymal transition is not required for lung metastasis but contributes to chemoresistance. Nature 2015;527:472-476.

50 Kurrey NK, Jalgaonkar SP, Joglekar AV, Ghanate AD, Chaskar PD, Doiphode RY, Bapat SA: Snail and slug mediate radioresistance and chemoresistance by antagonizing p53-mediated apoptosis and acquiring a stem-like phenotype in ovarian cancer cells. Stem Cells 2009;27:2059-2068.

51 Zhang P, Wei Y, Wang L, Debeb BG, Yuan Y, Zhang J, Yuan J, Wang M, Chen D, Sun Y, Woodward WA, Liu Y, Dean DC, Liang H, Hu Y, Ang KK, Hung MC, Chen J, Ma L: ATM-mediated stabilization of ZEB1 promotes DNA damage response and radioresistance through CHK1. Nat Cell Biol 2014;16:864-875.

52 Verghese S, Su TT: Drosophila Wnt and STAT Define Apoptosis-Resistant Epithelial Cells for Tissue Regeneration after Irradiation. PLoS Biol 2016;14:e1002536.

53 Hu B, Wang Q Wang YA, Hua S, Sauve CG, Ong D, Lan ZD, Chang Q Ho YW, Monasterio MM, Lu X, Zhong Y, Zhang J, Deng P, Tan Z, Wang G, Liao WT, Corley LJ, Yan H, Zhang J, You Y, Liu N, Cai L, Finocchiaro G, Phillips JJ, Berger MS, Spring DJ, Hu J, Sulman EP, Fuller GN, Chin L, Verhaak RG, DePinho RA: Epigenetic Activation of WNT5A Drives Glioblastoma Stem Cell Differentiation and Invasive Growth. Cell 2016;167:1281-1295 e1218.

-54 Suh HN, Kim MJ, Jung YS, Lien EM, Jun S, Park JI: Quiescence Exit of Tert(+) Stem Cells by Wnt/beta-Catenin Is Indispensable for Intestinal Regeneration. Cell Rep 2017;21:2571-2584.

55 Cojoc M, Peitzsch C, Kurth I, Trautmann F, Kunz-Schughart LA, Telegeev GD, Stakhovsky EA, Walker JR, Simin K, Lyle S, Fuessel S, Erdmann K, Wirth MP, Krause M, Baumann M, Dubrovska A: Aldehyde Dehydrogenase Is Regulated by beta-Catenin/TCF and Promotes Radioresistance in Prostate Cancer Progenitor Cells. Cancer Res 2015;75:1482-1494.

56 Lento W, Ito T, Zhao C, Harris JR, Huang W, Jiang C, Owzar K, Piryani S, Racioppi L, Chao N, Reya T: Loss of beta-catenin triggers oxidative stress and impairs hematopoietic regeneration. Genes Dev 2014;28:9951004.

57 Firat E, Niedermann G: FoxO proteins or loss of functional p53 maintain stemness of glioblastoma stem cells and survival after ionizing radiation plus PI3K/mTOR inhibition. Oncotarget 2016;7:54883-54896.

-58 Lobachevsky P, Leong T, Daly P, Smith J, Best N, Tomaszewski J, Thompson ER, Li N, Campbell IG, Martin RF, Martin OA: Compromized DNA repair as a basis for identification of cancer radiotherapy patients with extreme radiosensitivity. Cancer Lett 2016;383:212-219. 


\section{Cellular Physiology Cell Physiol Biochem 2018;48:419-432 \begin{tabular}{l|l} 
DOI: 10.1159/000491774 & $\begin{array}{l}\text { O } 2018 \text { The Author(s). Published by S. Karger AG, Basel } \\
\text { www.karger.com/cpb }\end{array}$
\end{tabular} \\ Zhao et al.: Wnt-Induced Cancer Radioresistance}

59 Jackson SP, Bartek J: The DNA-damage response in human biology and disease. Nature 2009;461:10711078.

60 Huen MS, Chen J: The DNA damage response pathways: at the crossroad of protein modifications. Cell Res 2008;18:8-16.

61 Bristow RG, Ozcelik H, Jalali F, Chan N, Vesprini D: Homologous recombination and prostate cancer: a model for novel DNA repair targets and therapies. Radiother Oncol 2007;83:220-230.

62 Wang WJ, Wu SP, Liu JB, Shi YS, Huang X, Zhang QB, Yao KT: MYC regulation of CHK1 and CHK2 promotes radioresistance in a stem cell-like population of nasopharyngeal carcinoma cells. Cancer Res 2013;73:1219-1231.

63 Guerra L, Albihn A, Tronnersjo S, Yan Q Guidi R, Stenerlow B, Sterzenbach T, Josenhans C, Fox JG, Schauer DB, Thelestam M, Larsson LG, Henriksson M, Frisan T: Myc is required for activation of the ATM-dependent checkpoints in response to DNA damage. PLoS One 2010;5:e8924.

-64 Karimaian A, Majidinia M, Bannazadeh Baghi H, Yousefi B: The crosstalk between Wnt/beta-catenin signaling pathway with DNA damage response and oxidative stress: Implications in cancer therapy. DNA Repair (Amst) 2017;51:14-19.

65 Idogawa M, Masutani M, Shitashige M, Honda K, Tokino T, Shinomura Y, Imai K, Hirohashi S, Yamada T: Ku70 and poly(ADP-ribose) polymerase-1 competitively regulate beta-catenin and T-cell factor-4mediated gene transactivation: possible linkage of DNA damage recognition and Wnt signaling. Cancer Res 2007;67:911-918.

66 Kaidi A, Williams AC, Paraskeva C: Interaction between beta-catenin and HIF-1 promotes cellular adaptation to hypoxia. Nat Cell Biol 2007;9:210-217.

67 Schmidt M, Fernandez de Mattos S, van der Horst A, Klompmaker R, Kops GJPL, Lam EWF, Burgering BMT, Medema RH: Cell Cycle Inhibition by FoxO Forkhead Transcription Factors Involves Downregulation of Cyclin D. Molecular and Cellular Biology 2002;22:7842-7852.

68 Kops GJPL, Medema RH, Glassford J, Essers MAG, Dijkers PF, Coffer PJ, Lam EWF, Burgering BMT: Control of Cell Cycle Exit and Entry by Protein Kinase B-Regulated Forkhead Transcription Factors. Molecular and Cellular Biology 2002;22:2025-2036.

69 Deng R, Tang J, Ma JG, Chen SP, Xia LP, Zhou WJ, Li DD, Feng GK, Zeng YX, Zhu XF: PKB/Akt promotes DSB repair in cancer cells through upregulating Mre11 expression following ionizing radiation. Oncogene 2011;30:944-955.

70 Chang HW, Nam HY, Kim HJ, Moon SY, Kim MR, Lee M, Kim GC, Kim SW, Kim SY: Effect of beta-catenin silencing in overcoming radioresistance of head and neck cancer cells by antagonizing the effects of AMPK on Ku70/Ku80. Head Neck 2016;38 Suppl 1:E1909-1917.

71 Luoto KR, Meng AX, Wasylishen AR, Zhao H, Coackley CL, Penn LZ, Bristow RG: Tumor cell kill by c-MYC depletion: role of MYC-regulated genes that control DNA double-strand break repair. Cancer Res 2010;70:8748-8759.

72 Hanahan D, Weinberg RA: Hallmarks of cancer: the next generation. Cell 2011;144:646-674.

73 Zhou L, Yuan R, Serggio L: Molecular mechanisms of irradiation-induced apoptosis. Front Biosci 2003;8:d919.

-74 Rehemtulla A, Hamilton CA, Chinnaiyan AM, Dixit VM: Ultraviolet radiation-induced apoptosis is mediated by activation of CD-95 (Fas/APO-1). J Biol Chem 1997;272:25783-25786.

-75 Caricchio R, Reap EA, Cohen PL: Fas/Fas ligand interactions are involved in ultraviolet-B-induced human lymphocyte apoptosis. J Immunol 1998;161:241-251.

-76 Gong B, Almasan A: Apo2 ligand/TNF-related apoptosis-inducing ligand and death receptor 5 mediate the apoptotic signaling induced by ionizing radiation in leukemic cells. Cancer Res 2000;60:5754-5760.

77 Burns TF, Bernhard EJ, El-Deiry WS: Tissue specific expression of p53 target genes suggests a key role for KILLER/DR5 in p53-dependent apoptosis in vivo. Oncogene 2001;20:4601-4612.

78 Su F, Overholtzer M, Besser D, Levine AJ: WISP-1 attenuates p53-mediated apoptosis in response to DNA damage through activation of the Akt kinase. Genes Dev 2002;16:46-57.

79 Tzeng HE, Yang L, Chen K, Wang Y, Liu YR, Pan SL, Gaur S, Hu S, Yen Y: The pan-PI3K inhibitor GDC-0941 activates canonical WNT signaling to confer resistance in TNBC cells: resistance reversal with WNT inhibitor. Oncotarget 2015;6:11061-11073. 


\section{Cellular Physiology Cell Physiol Biochem 2018;48:419-432

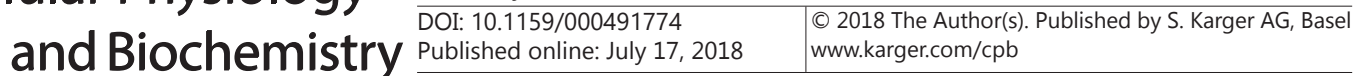 \\ Zhao et al.: Wnt-Induced Cancer Radioresistance}

80 Arques O, Chicote I, Puig I, Tenbaum SP, Argiles G, Dienstmann R, Fernandez N, Caratu G, Matito J, Silberschmidt D, Rodon J, Landolfi S, Prat A, Espin E, Charco R, Nuciforo P, Vivancos A, Shao W, Tabernero J, Palmer HG: Tankyrase Inhibition Blocks Wnt/beta-Catenin Pathway and Reverts Resistance to PI3K and AKT Inhibitors in the Treatment of Colorectal Cancer. Clin Cancer Res 2016;22:644-656.

-81 Pramanik KC, Fofaria NM, Gupta P, Ranjan A, Kim SH, Srivastava SK: Inhibition of beta-catenin signaling suppresses pancreatic tumor growth by disrupting nuclear beta-catenin/TCF-1 complex: critical role of STAT-3. Oncotarget 2015;6:11561-11574.

82 Yan S, Zhou C, Zhang W, Zhang G, Zhao X, Yang S, Wang Y, Lu N, Zhu H, Xu N: beta-Catenin/TCF pathway upregulates STAT3 expression in human esophageal squamous cell carcinoma. Cancer Lett 2008;271:8597.

83 Steinhusen U, Badock V, Bauer A, Behrens J, Wittman-Liebold B, Dorken B, Bommert K: Apoptosis-induced cleavage of beta-catenin by caspase-3 results in proteolytic fragments with reduced transactivation potential. J Biol Chem 2000;275:16345-16353.

84 Chen S, Guttridge DC, You Z, Zhang Z, Fribley A, Mayo MW, Kitajewski J, Wang CY: Wnt-1 signaling inhibits apoptosis by activating beta-catenin/T cell factor-mediated transcription. J Cell Biol 2001;152:87-96.

85 Zhang T, Otevrel T, Gao Z, Gao Z, Ehrlich SM, Fields JZ, Boman BM: Evidence that APC regulates survivin expression: a possible mechanism contributing to the stem cell origin of colon cancer. Cancer Res 2001;61:8664-8667.

-86 Zou M, Li Y, Xia S, Chu Q Xiao X, Qiu H, Chen Y, Zheng Z, Liu F, Zhuang L, Yu S: Knockdown of CAVEOLIN-1 Sensitizes Human Basal-Like Triple-Negative Breast Cancer Cells to Radiation. Cell Physiol Biochem 2017;44:778-791.

87 Leiker AJ, DeGraff W, Choudhuri R, Sowers AL, Thetford A, Cook JA, Van Waes C, Mitchell JB: Radiation Enhancement of Head and Neck Squamous Cell Carcinoma by the Dual PI3K/mTOR Inhibitor PF05212384. Clin Cancer Res 2015;21:2792-2801.

-88 Su H, Jin X, Zhang X, Zhao L, Lin B, Li L, Fei Z, Shen L, Fang Y, Pan H, Xie C: FH535 increases the radiosensitivity and reverses epithelial-to-mesenchymal transition of radioresistant esophageal cancer cell line KYSE-150R. J Transl Med 2015;13:104.

89 Liu J, Pan S, Hsieh MH, Ng N, Sun F, Wang T, Kasibhatla S, Schuller AG, Li AG, Cheng D, Li J, Tompkins C, Pferdekamper A, Steffy A, Cheng J, Kowal C, Phung V, Guo G, Wang Y, Graham MP, Flynn S, Brenner JC, Li C, Villarroel MC, Schultz PG, Wu X, McNamara P, Sellers WR, Petruzzelli L, Boral AL, Seidel HM, McLaughlin ME, Che J, Carey TE, Vanasse G, Harris JL: Targeting Wnt-driven cancer through the inhibition of Porcupine by LGK974. Proc Natl Acad Sci U S A 2013;110:20224-20229.

-90 Koo BK, van Es JH, van den Born M, Clevers H: Porcupine inhibitor suppresses paracrine Wnt-driven growth of Rnf43;Znrf3-mutant neoplasia. Proc Natl Acad Sci U S A 2015;112:7548-7550.

91 Huang SM, Mishina YM, Liu S, Cheung A, Stegmeier F, Michaud GA, Charlat O, Wiellette E, Zhang Y, Wiessner S, Hild M, Shi X, Wilson CJ, Mickanin C, Myer V, Fazal A, Tomlinson R, Serluca F, Shao W, Cheng H, Shultz M, Rau C, Schirle M, Schlegl J, Ghidelli S, Fawell S, Lu C, Curtis D, Kirschner MW, Lengauer C, Finan PM, Tallarico JA, Bouwmeester T, Porter JA, Bauer A, Cong F: Tankyrase inhibition stabilizes axin and antagonizes Wnt signalling. Nature 2009;461:614-620.

-92 Okada-Iwasaki R, Takahashi Y, Watanabe Y, Ishida H, Saito J, Nakai R, Asai A: The Discovery and Characterization of K-756, a Novel Wnt/beta-Catenin Pathway Inhibitor Targeting Tankyrase. Mol Cancer Ther 2016;15:1525-1534.

\$3 Jang GB, Hong IS, Kim RJ, Lee SY, Park SJ, Lee ES, Park JH, Yun CH, Chung JU, Lee KJ, Lee HY, Nam JS: Wnt/ beta-Catenin Small-Molecule Inhibitor CWP232228 Preferentially Inhibits the Growth of Breast Cancer Stem-like Cells. Cancer Res 2015;75:1691-1702.

94 Gonsalves FC, Klein K, Carson BB, Katz S, Ekas LA, Evans S, Nagourney R, Cardozo T, Brown AM, DasGupta R: An RNAi-based chemical genetic screen identifies three small-molecule inhibitors of the Wnt/wingless signaling pathway. Proc Natl Acad Sci U S A 2011;108:5954-5963.

$\$ 95$ Thorne CA, Hanson AJ, Schneider J, Tahinci E, Orton D, Cselenyi CS, Jernigan KK, Meyers KC, Hang BI, Waterson AG, Kim K, Melancon B, Ghidu VP, Sulikowski GA, LaFleur B, Salic A, Lee LA, Miller DM, 3rd, Lee E: Small-molecule inhibition of Wnt signaling through activation of casein kinase 1 alpha. Nat Chem Biol 2010;6:829-836. 